REGULAR ARTICLE

\title{
ETHNOMEDICINAL PLANTS USED BY KORWA TRIBE OF KORBA DISTRICT, CHHATTISGARH INDIA \\ SANDEEP SHUKLA*
}

\author{
Department of Botany, E. V. Government P. G. College, Korba (C. G.), India
}

\begin{abstract}
The paper deals ethnomedicinal information of Korwa tribe of Korba district. The tribe still using several plants to cure different disease, 30 plants belonging to different families, with their botanical names, family, vernacular name, month of flowering part used and uses given here. Basically Chhattisgarh is "The land of tribe" and because of abundance of the tribe Korwa, this region was named Korba. The information was collected through survey. During the survey knowledgeable person, vaid, were interviewed and information recorded. The data indicate the uses of 30 ethnomedicinal plants used to cure different disease. The tribe residing in the forest continues to utilize their traditional system of cure which is still effective and these plants are having great socio-economic importance. There are so many other plants other than the mentioned and there is a need to record the maximum information.
\end{abstract}

Keywords: Ethnomedicinal, Tribe, Vaid, Vernacular name, Socio-economic development.

\section{INTRODUCTION}

The people residing deep in the forest are totally depended on plants for their food, shelter, medicine, etc. The proper utilization of plants effects their socio-economic development. Herbal medicine is in existence still time immemorial in many parts of the world [1]. Earlier, studies of medicinal plant used by Himalayan tribes have been conducted by Bisht et al. [2]. Dhar et. al [3] done a case study on conservation of medicinal plants. Qureshi et al., [4] studied medicinal plants of Gilgit district and surrounding area in Pakistan and reported 27 medicinal plants. Ejaz-ul-Islam Dar [5] studied ethnobotanical uses of plant of Lawat district Muzzaffarabad. Idu et al. [6] studied ethnomedicinal flora of Otuo people of edo state, Nigeria. Some other workers e. g. Dongarwar [7], Saxena [8], Bhalla and Bhalla [9], Tosh [10], Yadav and Bhamare, [11] have also studied ethnobotanical and ethnomedicinal plants in different aspects.

The Korba District is known as the Industrial hub and Power Capital of Chattisgarh, India. Korba is situated between latitude $22-20{ }^{\circ} \mathrm{N}$ and longitude $82-42{ }^{\circ} \mathrm{E}$. Korba is an industrial district and also enriched with forest resources. The major tribes are-Kanwar, Gond, Binjhwar, Korwa etc. In which Korwa tribe has been struggling for their existence, they are few in number and living at hill region (www.korba.gov.in).

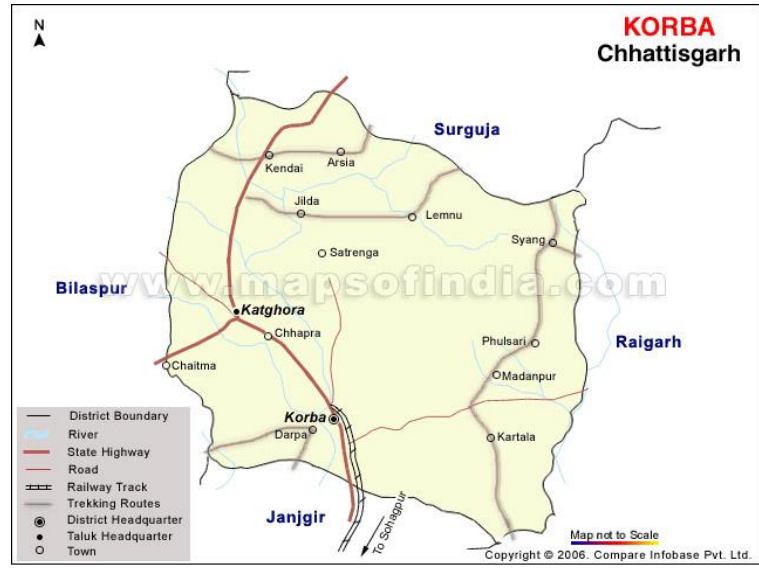

(www.mapsofindia.com)

The Korwa are Kolarian. Tribe found in Korba, mainly settled in hills. There are two subdivisions of KORWA-Kisan Korwa (live in planes) and Pahadi Korwa (live in hills). They are short statured with dark brown complexion and strongly built and active with good muscular development. Their fore head is narrow Pahadi Korwa have still blacker skin and wear minimum cloths. Generally, the Korwa tribes are landless and few have little land on which they cultivate the crops gondili and millets and they usually practice shifting cultivation (millets, pulses, maize, gram sweet potato etc.) They also collect MFP from forest areas such as medicinal plants, seeds, tendupatta, lac and other produce [12].

\author{
Received 19 February 2018; Accepted 28 April 2018 \\ ${ }^{*}$ Corresponding Author
}

Sandeep Shukla

Department of Botany, E. V. Government P. G. College, Korba (C. G.), India

Email: sandeepshukla21@yahoo.com

( $T$ This article is open access and licensed under the terms of the Creative Commons Attribution License (http://creativecommons.org/licenses/by/4.o/) which permits unrestricted, use, distribution and reproduction in any medium, or format for any purpose, even commercially provided the work is properly cited. Attribution - You must give appropriate credit, provide a link to the license, and indicate if changes were made. 
Korba is having rich forest cover and rich biodiversity heaving diverse flora. Korwa tribes. resides in the forest area and their life and livelihood is directly dependent upon forest products. They utilize the various product such as in the form of firewood, food, fodder, timber wood and medicines, this Korwa tribes are dependent upon their surrounding environment for all their needs. The Korwa tribes generally isolated people and having no relation with other communities and little of superstitions nature, they utilize these common plants to cure different disease and having good knowledge of the plants or herbs growing there [13].

This paper mainly deals with the study of medicinal plant used by Korwa tribe, even today ( 21 st century) herbal medicine plants play an important role in rural areas and still being used as household remedies. We have tried to study the common plants which used by Korwa tribes, gathered information and uses of that plants. So we can make efforts for the conservation and potential income to local people and to determine and monitor harvest levels of medicinal plants.

\section{Study area and method}

Our study areas included forest of Korba district and the place where Korwa tribes resides (Chhatasarai and Dudhitangar village). Including most of the people which depend on agriculture, agroforestry and forest resources. The study was conducted from June 2006 to May 2007. From there areas we have collected information regarding the usage of medicinal plants available in that area for treating various ailments and diseases. Information was collected directly by contacting elders, vaidya and knowledgeable person through a Questionnaire e. g.

- Medicinal plants found local area.

- Their Name

- Uses

- Method of using

- Which part is utilizing for medicinal purpose

- Object of collecting that plant.

-Time of collection

-For personal use

-For commercial use
The Plant material was collected and identification done by authenticated source.

\section{RESULTS AND DISCUSSION}

Forest are one of the most unique gift of nature and man has been dependent on plants for time immemorial forest produce includes a large variety of edible, industrial and commercial products. which have multifarious uses and in dispensable requirement of population leaving in around forests the volume and quantum of contribution of these products to our daily life is tremendous. The life of tribes intimately limited to forest product their basic needs and livelihood earnings are from processing and collection of these items. The tribals live in harmony with plants and the main interest of man in plants is sub systemic and find remedies for their miseries and ailments.

There are number of herbs with great therapeutic importance Rauwolfia Serpentina, root of which has been used for countries in traditional medicine as were for insanity epilepsy and high blood pressure, Gymenema is used for diabetes, Phyllanthus niruri for jaundice etc. Demand of the herbal health products are growing even if it is proving costlier then the corresponding is expensive synthetic one.

We learned through our survey that tribe are still dependent on plant resources for treatment of various ailments but this dependence is decreasing and the knowledge of herbal medicine and utilization of plant various remedies is reducing. In our study we have documented and identified 30 plant with their medicinal Important and tried to secure the traditional knowledge

-Resume of decreasing knowledge of herbal medicine-

1. Lack of belief 2. Declare of folk medicinal use of plants.

3. collection/harvest by dong manufactures.

4. Lack of systematic survey to identify the rare and endangered species.

5. Lack of market information and research.

6. Growing biotic pressure and consequent site degradation are not allowing its region in natural forest.

Following table 1 . Lists the medicinal plants species recorded from the sites studied and uses of plant parts for traditional ailment.

Table 1: Medicinal plants of Korba district with information collected on the basis of interview with Korwa tribe and local people

\begin{tabular}{|c|c|c|c|c|}
\hline Species & Family & $\begin{array}{l}\text { Vernacular } \\
\text { name }\end{array}$ & $\begin{array}{l}\text { Parts } \\
\text { used }\end{array}$ & Medicinal uses \\
\hline $\begin{array}{l}\text { Abrus } \\
\text { precatorius } \mathrm{L}\end{array}$ & FABACEAE & Gunj, Ratti & $\begin{array}{l}\text { White seeds, } \\
\text { Leaf }\end{array}$ & $\begin{array}{l}\text { preventing conception. } \\
\text { swelling in the body parts. } \\
\text { headache. }\end{array}$ \\
\hline $\begin{array}{l}\text { Acacia catechu } \\
\text { L. }\end{array}$ & MIMOSACEA & Khair, Kattha & Stem bark & night blindness (Rat-kana). \\
\hline $\begin{array}{l}\text { Amaranthus } \\
\text { viridis } \mathrm{L} \text {. }\end{array}$ & AMARANTHACEAE & Kanta bhaji & Root,leaf & $\begin{array}{l}\text { Root paste is applied on boils for suppuration. } \\
\text { Leaves are applied as poultice Sores. }\end{array}$ \\
\hline $\begin{array}{l}\text { Argemone } \\
\text { mexicana L. }\end{array}$ & PAPAVERACEAE & Pili kateri & Seed, Root & eczema. toothache. \\
\hline $\begin{array}{l}\text { Azadirachta } \\
\text { indica A. Juss. }\end{array}$ & MELIACEAE & Neem & Leaves & Diabetes and chicken pox \\
\hline $\begin{array}{l}\text { Androgaraphis } \\
\text { peniculata } \\
\text { Burm. }\end{array}$ & ACANTHACEAE & Chiraita. & $\begin{array}{l}\text { Stem bark, } \\
\text { Leaf }\end{array}$ & $\begin{array}{l}\text { loss of appetite } \\
\text { malaria }\end{array}$ \\
\hline Adhatoda & ACANTHACEAE & Adusa & Leaf & Asthma, malaria, Diarrhea \\
\hline
\end{tabular}




\begin{tabular}{|c|c|c|c|c|}
\hline $\begin{array}{l}\text { vasica Nees. } \\
\text { Abutilon }\end{array}$ & MALVACEAE & Kanghi & Leaf, Bark & Leaf paste is applied in Boils. \\
\hline $\begin{array}{l}\text { indicum } \mathrm{L} . \\
\text { Achyranthus } \\
\text { aspera } \mathrm{L} .\end{array}$ & AMARANTHACEAE & Chirchita & $\begin{array}{l}\text { Seed, Entire } \\
\text { plant, Fruits, } \\
\text { Leaf }\end{array}$ & $\begin{array}{l}\text { The decoction of the bark is taken in fever. } \\
\text { Cough, scorpion bite }\end{array}$ \\
\hline $\begin{array}{l}\text { Bambusa } \\
\text { arundinacea }\end{array}$ & POACEAE & Bans & Leaf & Boil, irregular menstruation. \\
\hline $\begin{array}{l}\text { Retz. } \\
\text { Buchanania } \\
\text { lanzan Spreng. }\end{array}$ & ANACARDIACEAE & $\begin{array}{l}\text { Char, Achar, } \\
\text { Chironji }\end{array}$ & $\begin{array}{l}\text { Leaves, Bark, } \\
\text { Seed }\end{array}$ & expectorant. \\
\hline $\begin{array}{l}\text { Butea } \\
\text { monosperma } \\
\text { Lamk. }\end{array}$ & FABACEAE & Palash, Parsa & $\begin{array}{l}\text { Flower, Bark, } \\
\text { Seed }\end{array}$ & $\begin{array}{l}\text { Contraceptive, } \\
\text { scabies }\end{array}$ \\
\hline $\begin{array}{l}\text { Boerhavia } \\
\text { diffusa L. }\end{array}$ & NYCTAGINACEAE & Punarnava & Whole plant & Jaundice, asthma. \\
\hline $\begin{array}{l}\text { Chlorophytum } \\
\text { tuberosum } \\
\text { Roxb. }\end{array}$ & LILIACEAE & $\begin{array}{l}\text { Koijhari } \\
\text { bhaji, safed } \\
\text { musli }\end{array}$ & Tuber & $\begin{array}{l}\text { Tuber powder is taken for stamina. Tuber } \\
\text { powder is taken in urinary problem. }\end{array}$ \\
\hline $\begin{array}{l}\text { Costus speciosus } \\
\text { J. Koenig }\end{array}$ & COSTACEAE & Keokand & Rhizome & Rhizome powder is purgative. \\
\hline $\begin{array}{l}\text { Gloriosa } \\
\text { superba } \mathrm{L} .\end{array}$ & LILIACEAE & Kalihari & Tuber, seed & $\begin{array}{l}\text { Tuber paste is applied and yaken to promote } \\
\text { labour pain. Seed powder is wormicidal (in } \\
\text { minute quantity). Tuber powder is taken in } \\
\text { stomachache }\end{array}$ \\
\hline $\begin{array}{l}\text { Gymnema } \\
\text { sylvestris Retz. } \\
\text { Hemidesmus } \\
\text { indicus } \text { R. Br. }\end{array}$ & $\begin{array}{l}\text { ASCLEPIADACEAE } \\
\text { ASCLEPIADACEAE }\end{array}$ & $\begin{array}{l}\text { Gurmar } \\
\text { Anantmul }\end{array}$ & $\begin{array}{l}\text { Leaf } \\
\text { Root, Latex }\end{array}$ & $\begin{array}{l}\text { Leaf powder is taken in diabetics. } \\
\text { Root powder is taken in urinary problem and } \\
\text { joint pain. Latex is applied on skin diseases. } \\
\text { Latex is taken as lactic agent. }\end{array}$ \\
\hline $\begin{array}{l}\text { Phyllanthus } \\
\text { niruri L. }\end{array}$ & EUPHORBIACEAE & Bhui amla & Entire plant & $\begin{array}{l}\text { Juice of whole plant is taken in jaundice. Juice of } \\
\text { plant is also taken in lever problem. }\end{array}$ \\
\hline $\begin{array}{l}\text { Pongamia } \\
\text { pinneta L. }\end{array}$ & FABACEAE & Karanj & Seed oil. & Seed oil is applied on skin diseases externally. \\
\hline $\begin{array}{l}\text { Pueraria } \\
\text { tuberosa Roxb. }\end{array}$ & FABACEAE & $\begin{array}{l}\text { Patal } \\
\text { kumhada. }\end{array}$ & Tuber & $\begin{array}{l}\text { Tuber powder is taken to increase stamina. } \\
\text { Tuber powder is diuretic. }\end{array}$ \\
\hline $\begin{array}{l}\text { Saccharum } \\
\text { munja Roxb. }\end{array}$ & POACEAE & Kans & Root & $\begin{array}{l}\text { Root powder is diuretic. } \\
\text { Root powder is taken in stomachache }\end{array}$ \\
\hline $\begin{array}{l}\text { Smilax } \\
\text { macrophylla } \\
\text { Roux. }\end{array}$ & LILIACEAE & Sher & Root, Stem & $\begin{array}{l}\text { Root powder is taken as tonic. } \\
\text { Root powder is taken in joint pain. } \\
\text { Stem is chewed in toothache. }\end{array}$ \\
\hline $\begin{array}{l}\text { Tephrosea } \\
\text { purpurea L. }\end{array}$ & FABACEAE & Sarphonk & Flower, Root & $\begin{array}{l}\text { Root powder is used for blood purifier. } \\
\text { Flower juice is taken to increase blood. }\end{array}$ \\
\hline $\begin{array}{l}\text { Terminalia } \\
\text { arjuna Roxb. }\end{array}$ & COMBRETACEAE & Kahua & Stem bark & $\begin{array}{l}\text { The bark of Arjuna is used in the form of powder } \\
\text { and decoction to treat heart diseases. Bark } \\
\text { powder is applied for skin. Bark powder is taken } \\
\text { in diarrhea. Seed powder is taken with honey in } \\
\text { cough }\end{array}$ \\
\hline $\begin{array}{l}\text { Terminalia } \\
\text { bellerica Rouxb. }\end{array}$ & COMBRETACEAE & Baheda & Fruit & $\begin{array}{l}\text { Fruit powder is taken in acidity. } \\
\text { Fruit powder is taken in asthama. }\end{array}$ \\
\hline $\begin{array}{l}\text { Terminalia } \\
\text { chebula Retz. }\end{array}$ & COMBRETACEAE & Harra & Fruit, Bark & $\begin{array}{l}\text { Fruit powder taken in night after meal in } \\
\text { constipation and other abdominal problem. } \\
\text { Roasted fruit pieces is chew in cough. Fruit } \\
\text { powder is taken in acidity. }\end{array}$ \\
\hline $\begin{array}{l}\text { Urginea indica } \\
\text { Roux. }\end{array}$ & LILIACEAE & Jangli pyaj & Bulb & $\begin{array}{l}\text { Bulb is used as Cardiotonic. } \\
\text { Crushed bulb is applied on joint pain. Seed } \\
\text { powder is taken twice in asthama. }\end{array}$ \\
\hline $\begin{array}{l}\text { Woodfordia } \\
\text { fruticosa } \mathrm{L} .\end{array}$ & LYTHRACEAE & Dhawai & Flower, Bark & $\begin{array}{l}\text { Entire flower is taken thrice in a day in } \\
\text { dysentery. Bark paste is applied on fresh wound } \\
\text { to stop bleeding }\end{array}$ \\
\hline $\begin{array}{l}\text { Ziziphus jujube } \\
\text { Lamk. }\end{array}$ & RHAMNACEAE & Boer, Ber & Fruit & $\begin{array}{l}\text { Fruit powder is taken in constipation. Fruit pulp } \\
\text { is applied on mouth ulcer. }\end{array}$ \\
\hline
\end{tabular}




\section{Research need in conservation practices for the rich biodiversity of medicinal plants}

We observed in our study that medicinal plants are being collected from wild habitats for domestic and commercial uses without any specific method to conserve them. This lack of effort to protect these sustainable resources may result in their depletion from natural habitats and also till now no quantitative assessments however available as to produce these medicinal plants. No information available about the amount consumed by local population and amount sold at markets. Efforts on scientific management of these medicinal plants is hampered due to increase in biotic pressure on forest leading to deforestation and degradation [12].

So far enhancing the production of these products from forest and other lands is essential to carry out studies on ecological and socio-economic aspects and also great need to create awareness among the indigenous communities about endangering medicinal plant if over exploited [13].

\section{CONCLUSION AND RECOMMENDATION}

We find that important knowledge of medicinal plants gathered by the Korwa tribe are needs to be determined in order to develop plans for their protection, improving Awareness, proper documentation of indigenous knowledge about the plants used by them.

The Study area is rich in medicinal plants and due to rich forest cover and diversity many important plants are found but due to lack of identification and improper knowledge they are not utilize. so there is need of creating awareness, motivating the local people for cultivation of medicinal plants and other economic species which can play an important role in economic development of area.

In this study of medicinal plants research and conservation efforts should be focused on the resources of the area and collected information should be utilizing to improve the production of medicinal and other useful plants in this area.

\section{REFERENCES}

1. Qureshi, R. A. and M. A. Ghufran, 2005. Medicinal Value of Some Important Roses and Allied Specie of
Northern Areas of Pakistan. Pakistan Rose Annual, Pictorial Printers (Pvt) Ltd., Islamabad, pp: 24-29.

2. Bisht, A. K., A. Bhatt, R. S. Rawal and U. Dhar, 2006. Prioritization and conservation of Himalayan medicinal plants: Angelica gliauca Edgew. As a case study. Ethnobotany Research and Application. 4;1124.

3. Dhar, U., R. S. Rawal and J. Upreti, 2000. Setting priorities for conservation of medicinal plants-a case study in Indian Himalaya. Biological Conservation. 95:57-65.

4. Qureshi, R. A., M. A. Ghufran, K. N. Sultana, M. Ashraf and A. G. Khan, 2008. Ethnobotanical studies of medicinal plants of Gilgit district and surrounding areas. Ethnobotany Research and Application 5:115122.

5. Ejaz-ul-Islam Dar, M., 2003. Ethnobotanical uses of plant of lawat district Muzaffrabad. Azad Jammu and Kashmir. Asian J. Plant Sci. 2:680-682.

6. Idu, M., H. I. Onyibe, O. Timothy and J. O. Erhabor, 2008. Ethnomedicinal flora of Otuo people of Edo state, Nigeria. Asian J. Plant Sci. 7:8-12

7. Dongarwar, N. M., 2004. Ethnobotanical studies on the trible of Jalgaon district of Maharastra StateIndia. J. Bot. Soc. Uni. Sagar. Vol. 39:130-137.

8. Saxena, O. P., 1970. The flora of Amarkantak (Madhaya Pradesh). Bull. Bot. Surv. India. 12: 37-66.

9. Bhalla, S. and N. P. Bhalla, 2004. Ethnobotany: Basic aspects and links between scientist and tribals for future aspects. J. Bot. Soc. Univ. Sagar, Vol. 39:138143 .

10. Tosh, J., 1996. Ethnobotanical study of western Maharastra. J. Econ. Tax. Bot. Addl. Ser. 12:169-174.

11. Yadav, S. S. and P. B. Bhamare,1989. EthnomedicoBotanical studies of Dhule forest in maharastra State (india). J. Econ. Tax. Bot. 13: 455-460.

12. Singh, A. K. and A. P. Sinha, 1987. Bharat ke Adivasi. Published by Vishal Publishing House, Parvati Printing Press Ranchi, Ranchi, India.

13. Shukla, S., 2007. Study of ethnobotanical plants used by Korwa tribe of Korba district, Chhattisgarh. M. Phill Thesis, Periyar University, Salem. 